\title{
DETERMINATION OF FOOD PRESERVATIVES (BENZOIC AND SORBIC ACIDS) IN BAKERY PRODUCTS OF DISTRICT PESHAWAR, PAKISTAN
}

\author{
Adeela Mustafa, Romana Ayub, Sidra Irfan, Bushra Iftikhar, Mahnoor Inamullah \\ Department of Community Medicine, Khyber Medical College, Peshawar - Pakistan
}

\begin{abstract}
Objective: To determine the level of preservatives (Benzoic and Sorbic acid) in bakery products of Peshawar

Material and methods: This cross-sectional study was performed in district Peshawar from August 2019 to December 2019 by visiting four bakery stores in each union council (total of ten union councils) by collecting three samples (of biscuits, cakes and bread) from each bakery stores using multistage convenient sampling technique. Thus, a total of 120 samples were collected. Food additives in the form of Benzoic and Sorbic acid were checked in Forensic and toxicology laboratory of Khyber medical college Peshawar. Data was analyzed using SPSS 23, where frequencies and percentages were used for categorical variables and mean. Standard deviation for numerical data.
\end{abstract}

Results: In samples of cakes, concentration of benzoic acid (BA) ranged from 314 to 457 ppm (WHO permissible limit is up to $500 \mathrm{ppm}$ ) while that of sorbic acid(SA) ranged from 597 to $859 \mathrm{ppm}$ (WHO permissible limit is up to 1000ppm). Similarly, concentration of benzoic acid in biscuits samples ranged from 363 to 467 ppm and sorbic acid ranged from 649 to 895 ppm. In bread samples, BA ranged from 350 - 487 ppm and sorbic acid ranged from 619 to 944 . Comparing the values with WHO standards for preservatives, the concentration of benzoic and sorbic acid is found to be within permissible limits with $p$ value $<0.05$

Conclusion: Benzoic acid and Sorbic acid were found in permissible limits in 3 bakery products in the city of Peshawar, as set by World Health Organization.

Keywords: Bakery products, Additives, Preservatives, Bakeries

This article may be cited as: Mustafa A, Ayub R, Irfan S, Iftikhar B, Inamullah M. Determination of food preservatives (Benzoic and Sorbic Acids) in bakery products of district Peshawar, Pakistan. J Med Sci 2021 July;29(3):87-90

\section{INTRODUCTION}

When we have to store food for a prolonged period, additives are added to maintain the quality and the taste. These additives stop bacteria and fungus from growing by removing additional water ${ }^{1}$. Preservation of food is one of the oldest methods used by people that can inhibit changes which occur due to action of microbes, enzymes and physical agents ${ }^{2,3}$. A preservative can be natural or synthetic, which we add to food to prevent deterioration by bacteria or atmospheric effects. Chemical preservatives such as Sulphur dioxide, sorbic acid, propionic acid and sodium benzoate are increasingly used by the baking industry mainly because of high demand for good quality, safe and

\section{Correspondence}

Dr Romana Ayub

Associate Professor

Department of Community Medicine, Khyber Medical

College, Peshawar - Pakistan

Email: rumi.inam@gmail.com

Cell: +92-300-5954850

Date received: 05-03-2021

Date revised: $\quad 22-09-2021$

Date accepted: 24-09-2021 fresh food ${ }^{4,5}$. Preservatives when added to food minimize food wastage which can be caused by microbes. In this way these can be stored in stores and homes for longer period $^{6}$.

Bakery Products have an important place in food consumption ${ }^{7}$. Commonly consumed bakery products are bread, biscuits and cakes which make up to $80 \%$ of the products produced in most of the countries ${ }^{8}$. Changing life styles and dietary habits have resulted in increased demand of ready to eat food ${ }^{9}$. Foods in which preservatives are used because of their antimicrobial activity are cakes, butter, pie and doughnuts ${ }^{10}$. Studies have proven that on an average, every individual can annually consume up to 3 to $5 \mathrm{~kg}$ or even higher quantity of food additives ${ }^{11}$. Additives are mostly added to all forms of food, ranging from the less processed to the highly processed ones ${ }^{12}$.

The association between added chemicals and the health is not a good one. In the 1980s, food chemicals were thought to be harmful to be used by humans, which resulted in fear of using them, and some of them were excluded from list. Later, it was proven by different studies that not 
Determination Of Food Preservatives (Benzoic And Sorbic Acids) In Bakery Products Of District Peshawar, Pakistan

all of them were harmful, although there were doubts about the effects of these on health ${ }^{13}$. Like any other medicinal chemical, preservatives can initiate hazardous reactions like allergic reactions and even carcinogenesis ${ }^{14}$. Many studies have shown that particular levels of artificial preservatives and their long-term use can cause carcinogenicity and genotoxicity ${ }^{15,16}$. Recent research is encouraging the use of agents that are natural and have got antimicrobial activity to replace the commonly used synthetic preservatives thus reducing their hazardous impact over health ${ }^{17}$. While in Pakistan, the quality control measures are inadequate, studies to estimate the levels of food preservatives are not yet conducted at all in our province. This study will highlight the level of food preservatives that will help food control authority to regulate the quality and standards of bakery products in the district Peshawar.

\section{MATERIAL AND METHODS}

This cross-sectional study was performed in the district Peshawar from August 2019 to December 2019 by visiting four bakery stores in each union council, in a total of ten union councils by collecting three samples of (biscuits, cakes and bread) from each bakery store using multistage convenient sampling technique. Thus, a total of 120 samples were collected. Sample size was calculated using WHO sample size calculator, using Prevalence of 93\% of benzoic acid found in bakery products in study conducted in Iran $^{18}$. After collection of samples, the analysis was done by High Performance Liquid Chromatography in Forensic and toxicology laboratory of Khyber Medical College Peshawar.

\section{RESULTS}

In samples of cakes, concentration of benzoic acid (BA) ranged from 314 to 457 ppm (WHO permissible limit is up to $500 \mathrm{ppm}$ ) while that of sorbic acid(SA) ranged from 597 to 859 ppm (WHO permissible limit is up to 1000ppm). Similarly, concentration of benzoic acid in biscuits samples ranged from 363 to $467 \mathrm{ppm}$ and sorbic acid ranged from 649 to 895 ppm. In bread samples, BA ranged from 350 - 487 ppm and sorbic acid ranged from 619 to 944. Comparing the values with WHO standards for preservatives, the concentration of benzoic and sorbic acid is found to be within permissible limits with $p$ value $<0.05$. See table 1-6 for details. Fig-1 shows level of benzoic and Sorbic acids in three food products.

\section{DISCUSSION}

The results of this study revealed that preservatives are present in all bakery products and they are found to be
Table 1: Frequency of different types of bakery products

\begin{tabular}{|c|c|c|}
\hline $\begin{array}{c}\text { Types of bakery } \\
\text { product }\end{array}$ & Product No & Percentage \\
\hline Bread & 40 & $33.3 \%$ \\
\hline Biscuit & 40 & $33.3 \%$ \\
\hline Cake/Pastery & 40 & $33.3 \%$ \\
\hline Total & 120 & $100.0 \%$ \\
\hline
\end{tabular}

Table 2: Comparison of Food preservatives (BA \& SA) in Cakes in Different Union Councils

\begin{tabular}{|c|c|c|}
\hline UCs & $\begin{array}{c}\text { Benzoic acid: } \\
\text { Mean \& (S D) }\end{array}$ & $\begin{array}{c}\text { Sorbic acid: } \\
\text { Mean (SD) }\end{array}$ \\
\hline UC 1 & $449.25(8.18)$ & $836.75(45.828)$ \\
\hline UC 2 & $455.00(8.446)$ & $859.50(55.842)$ \\
\hline UC 3 & $451.50(22.487)$ & $789.50(173.09)$ \\
\hline UC 4 & $454.50(25.736)$ & $811.25(50.566)$ \\
\hline UC 5 & $419.75(49.149)$ & $852.00(141.393)$ \\
\hline UC 6 & $457.75(75.522)$ & $663.25(59.011)$ \\
\hline UC 7 & $389.50(74.942)$ & $597.00(141.353)$ \\
\hline UC 8 & $374.25(67.342)$ & $759.75(74.437)$ \\
\hline UC 9 & $390.75(76.443)$ & $728.25(186.382)$ \\
\hline UC 10 & $314.00(60.619)$ & $612.25(33.180)$ \\
\hline
\end{tabular}

Table 3: Comparison of Food Preservatives (SA\&BA) in Bread in different Union Councils

\begin{tabular}{|c|c|c|}
\hline UCs & $\begin{array}{c}\text { Benzoic acid } \\
\text { mean \& (SD) }\end{array}$ & $\begin{array}{c}\text { Sorbic acid } \\
\text { mean \& (SD) }\end{array}$ \\
\hline UC 1 & $487.75(29.159)$ & $812.00(59.121)$ \\
\hline UC 2 & $472.00(26.633)$ & $813.50(47.007)$ \\
\hline UC 3 & $461.00(40.042)$ & $825.50(110.147)$ \\
\hline UC 4 & $409.50(60.341)$ & $944.25(34.121)$ \\
\hline UC 5 & $400.25(15.064)$ & $807.25(116.554)$ \\
\hline UC 6 & $376.75(107.398)$ & $697.00(146.592)$ \\
\hline UC 7 & $350.00(87.939)$ & $827.75(69.687)$ \\
\hline UC 8 & $380.75(105.844)$ & $619.50(114.684)$ \\
\hline UC 9 & $404.25(92.330)$ & $727.00(171.587)$ \\
\hline UC 10 & $373.50(101.773)$ & $872.50(94.296)$ \\
\hline
\end{tabular}

Table 4: Comparison of Preservatives (BA \&SA) in Biscuits in different Union councils

\begin{tabular}{|c|c|c|}
\hline UCs & $\begin{array}{c}\text { Benzoic acid } \\
\text { mean \& (SD) }\end{array}$ & $\begin{array}{c}\text { Sorbic acid } \\
\text { mean \& (SD) }\end{array}$ \\
\hline UC 1 & $458.75(45.683)$ & $886.00(25.073)$ \\
\hline UC 2 & $460.75(13.276)$ & $889.50(90.780)$ \\
\hline UC 3 & $467.25(24.245)$ & $753.00(42.591)$ \\
\hline UC 4 & $450.25(51.803)$ & $721.50(183.945)$ \\
\hline UC 5 & $436.50(48.446)$ & $841.50(116.119)$ \\
\hline UC 6 & $364.00(93.192)$ & $701.50(72.247)$ \\
\hline UC 7 & $376.50(32.808)$ & $895.75(93.870$ \\
\hline UC 8 & $403.50(32.563)$ & $829.25(93.870)$ \\
\hline UC 9 & $394.75(128.181)$ & $649.75(150.050)$ \\
\hline UC 10 & $363.75(68.070)$ & $815.00(179.907)$ \\
\hline
\end{tabular}


Determination Of Food Preservatives (Benzoic And Sorbic Acids) In Bakery Products Of District Peshawar, Pakistan

Table 5: Comparison of Benzoic acid with FDA criteria applying (one sample T test)

\begin{tabular}{|c|c|c|c|c|c|c|c|}
\hline \multirow{2}{*}{$\begin{array}{c}\text { Level of BA in bis- } \\
\text { cuits }\end{array}$} & Test value & T test & DF & sig & Mean Difference & \multicolumn{2}{|c|}{ 95\% C.I } \\
\cline { 2 - 8 } & 500 & -21.600 & 39 & 0.001 & -260.40 & -284.78 & -236.01 \\
\hline Level of BA in cake & 1000 & -75.24 & 39 & .0001 & -683.87 & -702.25 & -665.49 \\
\hline Level of BA in bread & 500 & 14.59 & 39 & .0001 & 294.62 & 253.79 & 335.45 \\
\hline
\end{tabular}

$P$ value $=0.0001$

Table 6: Comparison of Sorbic acid levels with FDA criteria (one sample t-test)

\begin{tabular}{|c|c|c|c|c|c|c|c|}
\hline \multirow{2}{*}{ SA in biscuits } & Test value & T test & DF & \multirow{2}{*}{ sig } & Mean Difference & \multicolumn{2}{|c|}{ 95\% C.I } \\
\cline { 3 - 8 } & & & & & & Lower & Upper \\
\cline { 2 - 8 } & 500 & 9.73 & 39 & 0.0001 & -201.72 & -243.6 & -159.7 \\
\hline SA in cake & 1000 & -58.5 & 39 & 0.0001 & -124.05 & -129.2 & -1205.8 \\
\hline SA in bread & 500 & 14.59 & 39 & 0.0001 & 294.62 & 253.79 & 335.45 \\
\hline
\end{tabular}

$P$ value $=0.0001$

$\mathrm{Cl}$ is also significant

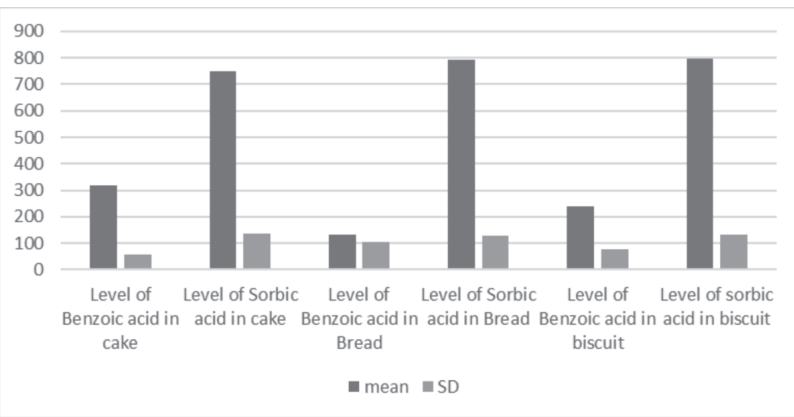

Fig 1: Comparison of Benzoic and Sorbic Acid in three food products

within permissible limits set by WHO. Intake of food exceeding the minimum permissible carries a definite health risk, but at the same time these risks carry a strong association with level of consumption and accurate calculation of these additives. Studies have shown that safe food practices result in healthy population which improves the economic growth of those countries. WHO has set certain standards for food additives so that they cause less toxicity because it is proven that food additives cause genetic mutations if consumed in large amounts ${ }^{19}$. Different countries either use the WHO criteria for preservative addition or set their own standards which is consistent the findings of this study where in Pakistan WHO set standards are followed ${ }^{20}$. The addition of natural ingredients to bakery products in our study is consistent with the practice in developed countries where demand for "clean label" is being introduced and people of the bakery industry are deviating from using chemicals as food additives ${ }^{21}$. Studies carried out in most of the countries show that Benzoic acid and Sorbic acid are frequently used preservatives either alone or together. In our study, sorbic acid and benzoic acid levels in cake samples are found mixed together within the range of 595$859 \mathrm{ppm}$ and 314-457 ppm respectively. A study conducted in Egypt by Mahmoud Gamal reported that the levels of
Sorbic acid in cake were $288-659$ ppm while benzoic acid was not detected. These findings are not consistent with our study which shows that both the preservatives are present together ${ }^{22}$. A study in Iran reported the levels of benzoic acid were from 350 to $1520 \mathrm{ppm}$ while sorbic acid was found to be from 850 to $2300 \mathrm{ppm}$ in bread samples. The results showed that benzoic acid and sorbic acid widely occur in food products in Iran. This study results also show that great variation is found in preservative added to food from country to country \& region to region, so the associated health risks also differ ${ }^{23}$. Samples in case of Iran show no benzoic acid at all. Another finding which was not consistent with the results of our study was detection of both these additives in bread sample. Again, the levels were lower in samples of Iran and benzoic acid was not detected in their samples. This also shows that different countries use their own criteria at times ${ }^{24}$.

The results of our study show that level of benzoic acid and Sorbic acid in cake differ from cake samples checked in Yemen and Iran where the study showed that the levels of these preservatives was found to be lower, while samples in case of Iran show no benzoic acid at all. Another finding which was not consistent with the results of our study was detection of both these additives in bread sample ${ }^{25}$.

This study has limitations in many respects, the samples are taken from one city where public health regulations are adopted stringently. Sample collection from areas out of main cities might show variations in preservatives use. Another limitation of this study is the fact that we selected only three bakery products.

\section{CONCLUSION}

Benzoic acid \& Sorbic acid were found in permissible limits in these bakery products, as set by World Health Organization. Large sample size including multiple products 
and venues in far flung areas are needed to estimate the true magnitude of preservatives addition in food products.

\section{REFERENCES}

1. Badora A, Bawolska K, Kozłowska-Strawska J, Domańska J. Food additives in food products: A case study. InNutrition in health and disease-our challenges now and forthcoming time 2019 Apr 9. IntechOpen.

2. Mpountoukas P, Vantarakis A, Sivridis E, Lialiaris T. Cytogenetic study in cultured human lymphocytes treated with three commonly used preservatives. Food and Chemical Toxicology. 2008 Jul 1;46(7):2390-3.

3. Da Costa Cardoso LA, Kanno KY, Karp SG. Microbial production of carotenoids A review. African Journal of Biotechnology. 2017 Jan 25;16(4):139-46.

4. Carocho M, Morales P, Ferreira IC. Natural food additives: Quo vadis?. Trends in Food Science \& Technology. 2015 Oct 1;45(2):284-95.

5. Thomas OE, Adegoke OA. Toxicity of food colours and additives: A review. African Journal of Pharmacy and Pharmacology. 2015 Sep 29;9(36):900-14

6. Saranraj P, Geetha M. Microbial spoilage of bakery products and its control by preservatives. International Journal of Pharmaceutical \& biological archives. 2012;3(1):38-48.

7. Silva MM, Lidon FC. An overview on applications and side effects of antioxidant food additives. Emirates Journal of Food and Agriculture. 2016 Jan 1:823-32.

8. Al-Shammari E, Bano R, Khan S, Shankity I. The effect of preservatives and flavour additive on the production of oxygen-free radicals by isolated human neutrophils. Inte J Nutri Food Sci. 2014;3(3):210-5.

9. Burana-osot J, Arunsingkharat L, Naksuk M, Naungnamjai S, Saetun T. Validation of a HPLC method for the determination of benzoic acid and sorbic acid in noodles. Chiang Mai J. Sci. 2014 Apr 1;41(2):370-82.

10. Polônio ML, Peres F. Food additive intake and health effects: public health challenges in Brazil. Cadernos de saude publica. 2009 Aug;25(8):1653-66.

11. Zengin N, Yüzbaşığlu D, Ünal F, Yılmaz S, Aksoy H. The evaluation of the genotoxicity of two food preservatives: sodium benzoate and potassium benzoate. Food and Chemical Toxicology. 2011 Apr 1;49(4):763-9.

12. Carocho M, Morales P, Ferreira IC. Natural food additives: Quo vadis?. Trends in Food Science \& Technology. 2015 Oct 1;45(2):284-95.

13. Carocho M, Morales P, Ferreira IC. Natural food additives: Quo vadis?. Trends in Food Science \& Technology. 2015 Oct 1;45(2):284-95.

14. da Costa Cardoso LA, Kanno KY, Karp SG. Microbial production of carotenoids A review. African Journal of Biotechnology. 2017 Jan 25;16(4):139-46.

15. Mischek D, Krapfenbauer-Cermak C. Exposure assessment of food preservatives (sulphites, benzoic and sorbic acid) in Austria. Food Additives \& Contaminants: Part A. 2012 Mar 1;29(3):371-82.

16. Kumar C, Shetake N, Desai S, Kumar A, Samuel G, Pandey $B N$. Relevance of radiobiological concepts in radionuclide therapy of cancer. International journal of radiation biology. 2016 Apr 2;92(4):173-86.
17. Xu C, Liu J, Feng C, Lv H, Lv S, Ge D, Zhu K. Investigation of benzoic acid and sorbic acid in snack foods in Jilin province, China. International Journal of Food Properties. 2019 Jan 1;22(1):670-7.

18. Chaleshtori FS, Arian A, Chaleshtori RS. Assessment of sodium benzoate and potassium sorbate preservatives in some products in Kashan, Iran with estimation of human health risk. Food and chemical toxicology. 2018 Oct 1;120:634-8.

19. Mischek D, Krapfenbauer-Cermak C. Exposure assessment of food preservatives (sulphites, benzoic and sorbic acid) in Austria. Food Additives \& Contaminants: Part A. $2012 \operatorname{Mar} 1 ; 29(3): 371-82$.

20. KARATAŞLI M, ÇAKMAK B, ÖZPINAR $H$. investigation of sorbic acid and benzoic acid amount of some food exposed for sale in istanbul. International Journal of Food Engineering Research.;2(2):43-58.

21. Nascimento KD, Paes SD, Augusta IM. A Review'Clean Labeling:: Applications of Natural Ingredients in Bakery Products. Journal of Food and Nutrition Research. 2018;6(5):285-94 .

22. Martyn DM, McNulty BA, Nugent AP, Gibney MJ. Food additives and preschool children. Proceedings of the Nutrition Society. 2013 Feb;72(1):109-16.

23. Lennerz BS, Vafai SB, Delaney NF, Clish CB, Deik AA, Pierce KA, Ludwig DS, Mootha VK. Effects of sodium benzoate, a widely used food preservative, on glucose homeostasis and metabolic profiles in humans. Molecular genetics and metabolism. 2015 Jan 1;114(1):73-9.

24. Akintonwa A, Awodele O, Emeka PM, Osajare O. The mutagenic potentials of potassium bromate and some commonly used food additives. African Journal of Biotechnology. 2007;6(8).

25. Mihyar GF, Yousif AK, Yamani MI. Determination of benzoic and sorbic acids in labaneh by high-performance liquid chromatography. Journal of food composition and analysis. 1999 Mar 1;12(1):53-61.

CONFLICT OF INTEREST: Authors declare no conflict of interest

GRANT SUPPORT AND FINANCIAL DISCLOSURE: NIL

\section{AUTHOR'S CONTRIBUTION}

Following authors have made substantial contributions to the manuscript as under

Mustafa A: Helped in literature review, data analysis and writeup.

Ayub R: $\quad$ Conceived study, collected data and did literature review and data analysis.

Irfan S: $\quad$ literature review and Writeup.

Iftikhar B: Data analysis, critical review, overall supervision

Inamullah M: Bibilography

Authors agree to be accountable for all aspects of the work in ensuring that questions related to the accuracy or integrity of any part of the work are appropriately investigated and resolved. 